\title{
The impact of Learning Development tutorials on student attainment
}

\author{
Alison Loddick \\ University of Northampton \\ Kate Coulson \\ University of Northampton
}

\section{Abstract}

University Learning Development teams provide expert advice to learners regarding the development and enhancement of academic skills such as essay writing, dissertations, critical analysis, mathematics, and statistics. The majority of universities have set up Learning Development or similar academic support services in recent years. However, little research has been conducted to understand the effect of such help on student attainment. At the University of Northampton, this service is perceived as pivotal in supporting students through their studies. The impact on student grades and future attainment was examined using three and a half years of student assessment data (over 16,000 students and 175,000 assessments) which was connected to information gathered from the Learning Development one-to-one tutorials database. Although causality cannot be claimed, there was an average rise of one to two sub grades for learners who attended at least one Learning Development tutorial compared to those who did not use this assistance. Furthermore, historical tutorials positively affected grades of students with an additional two percent increase in their future assignments. Students from the faculties of Business and Law and Education and Humanities saw the largest increase in attainment compared to students within their faculties who did not have tutorials. Furthermore, students from a black ethnic background and aged 25 years or below also gained the most in terms of attainment compared to other ethnic groups and more mature students.

Keywords: Learning Development; tutorial; attainment; users; academic skills. 


\section{Background}

The UK provision for Learning Development commenced and expanded as a consequence of the development of higher education and the widening student participation agenda of the 1990s. Tony Blair announced in 1999 the government's target to boost the proportion of 'young adults' attending higher education to 50 percent (Blair, 1999). As a result of this, the student profile diversified and now has a wider variety of cultural and social backgrounds (Universities UK, 2017). Universities adapted to these changes and focussed further on student learning, developing new roles within the universities to advise students (Hilsdon, 2011). Today, the majority of higher education institutions have academic support services such as Learning Development for their students. Eighty-eight out of 103 universities surveyed by Sigma in 2012 stated that they offered additional learning support in mathematics (Perkin, Lawson, and Croft, 2012). Although this survey did not ask about all study skills, mathematics does fall under this remit.

The Learning Development team at the University of Northampton has supported students' academic skills (including mathematics and statistics) since 1991. As of October 2017, there were 9,004 undergraduate students, studying 204 programmes. It currently has seven and a half full-time equivalent staff supporting students' academic skills through workshops, one-to-one tutorials and a drop-in service. The QAA in 2009 described the work of the University of Northampton's Learning Development team as exemplary practice, that was valued by students and represented an innovative approach to student support that was readily accessible for student learning (QAA, 2009). Nevertheless, the team continuously needs to demonstrate it provides 'value for money'. This research attempts to demonstrate how the Learning Development team at the University of Northampton provide 'value for money' through supporting and improving students' academic skills by examining how their tutorial system relates to student attainment.

\section{Previous research}


Research on Learning Development users and the impact of Learning Development tutorials on student attainment is limited. Most studies confirm a positive impact of tutorials on student attainment (MacGillivray, 2009; Manalo et al., 2009; Choudhary and Malthus, 2017). There is some research looking at the impact of transition courses that teach academic skills over several weeks prior to a student commencing university. Although transition courses are not the same as one-to-one tutorials, they do demonstrate the impact of developing students' academic skills. These courses also show increases in student attainment (Murphy et al., 2010; Strayhorn, 2011; Wibrowski et al., 2017).

Buchanan (2015) examined users of Learning Development to support future service development. The research found that students using the service were more likely to be female and of black or minority ethnic background (BME) compared to the university student profile. The users were also from a wide range of academic abilities with average percentage marks from 37.67 up to 71.63 . However, the research only looked at the users of their service and not the intervention impact on student attainment. Buchanan's research also failed to differentiate different types of service users, assuming students were the same whether they received a tutorial, drop-in appointment or workshop and included all students whether undergraduate or postgraduate.

Research by Manalo et al. (2009) and MacGillivray (2009) discovered a positive effect on student achievement from tutorials. Manalo, Marshall, and Fraser examined the impact of one-to-one assignment writing assistance in a nursing degree. The course lecturers encouraged students to seek support from their Learning Development service. Of those students who received assistance, $97 \%$ passed both courses, while the pass rate was $48 \%$ for those students who did not receive assistance. The study pointed out that other factors could have affected attainment, and that the tutorials were voluntary and therefore students chose to engage in the process but concluded that their findings suggested that the service had a significant impact on results. However, this study was based on a small number of students - thirty-seven students receiving assistance compared to twenty-one students not receiving assistance - and only included students from one course at the university. MacGillivray's ( 2009) findings were less conclusive. Her research examined the impact of mathematics and statistics tutorials on students commencing the first-year mathematics and statistics courses on mathematics degree programs at the Queensland University of Technology between 2003 and 2007. The results showed that mean 
attainment increased in all courses where students had at least one tutorial. However, the $95 \%$ confidence intervals overlapped in most courses, showing less confidence in the findings. The research also looked at engineering students who had a significant increase in grade point average with tutorials compared to those that did not.

In addition, Choundhary and Malthus (2017) explored the effect of mathematics tutorials over a 10-week period with first year students studying for a undergraduate degree in nursing. The students attended at least five 1-hour tutorials, either in small groups or on a one-to-one basis. The students completed numeracy tests before and after the 10-week period. Before the intervention, the numeracy results varied between $13.3 \%$ and $100 \%$. After the intervention, they increased to between $60 \%$ and $100 \%$. The results increased in 16 out of the 27 students and the other 11 had over 86 per cent correct in the first numeracy test suggesting less room for improvement. This paper concluded that tutorials had an impact on attainment, however, the sample size was small $(n=27)$ and they only looked at numeracy skills and not at all academic skills. Furthermore, students received at least five tutorials of support and the research did not examine the effect of fewer tutorials.

In terms of finding improvement in attainment for students following academic studies support, there is research demonstrating improvement in academic results and retention from specific interventions such as bridging or transition courses ( Murphy et al., 2010; Strayhorn, 2011; Wibrowski et al., 2017). Wibrowski et al. (2017) found that students from disadvantaged backgrounds who enrolled on a programme to develop their academic skills at the start of their first year at university improved their assessment grades to either similar or higher levels than first year students that did not enrol onto the programme. Strayhorn (2011) found that summer bridging programmes positively affected academic skills and academic self-efficacy, and that the students' positive beliefs about academic ability predicted $30 \%$ of the variance in first-semester grades in college. Although both Wibroski's and Strayhorn's studies were based on small samples (176 and 55 students respectively), they provide evidence that additional academic support impacts student attainment. However, both programmes included several intensive weeks of an academic programme in the summer before students started university and do not examine the impact of one-to-one tutorials. 
The literature, in the main, showed that supporting students' academic skills can improve student attainment, although all the studies were based on small sample sizes.

\section{Methods}

This research explores the impact of one-to-one Learning Development tutorials upon attainment. Tutorials were chosen as they provided the longest period of one-to-one support on specific student needs. The tutorials were 25-minute one-to-one sessions (or 55 minutes for mathematics and statistics) where students asked for academic support during their studies. The tutorial sessions could be face-to-face, online or via the telephone. The students mainly had tutorials with Learning Development to support essay and dissertation writing, and to support their quantitative maths and statistics studies (See table 1). Students may have also attended Learning Development in drop-ins and workshops, although the interaction between delivery methods is excluded from this analysis. The choice of using tutorials only was made as it was felt through experience that this would have the largest impact on attainment and that 10-minute drop-ins would not have the time to majorly impact attainment. Utilising workshop attendance data would have been excessively time consuming.

Table 1. Learning Development tutorial topics for undergraduate and postgraduate studies at the University of Northampton between 1st September 2016 and 31 st August 2017.

\begin{tabular}{|l|l|l|}
\hline Tutorial Topic & Count & Percentage \\
\hline & & \\
Essays and Assignments & 1206 & 42.4 \\
Dissertations & 478 & 16.8 \\
Maths/Stats/SPSS & 226 & 8.0 \\
Academic Writing & 204 & 7.2 \\
Literature Review & 151 & 5.3 \\
Critical Analysis & 125 & 4.4 \\
Referencing & 106 & 3.7 \\
Presentations & 68 & 2.4
\end{tabular}




\begin{tabular}{|l|l|l|} 
Reports & 67 & 2.4 \\
Planning/Time management & 40 & 1.4 \\
\hline No topic & 51 & 2 \\
Other & 119 & 4.2 \\
Total & 2841 & 100.0 \\
\hline
\end{tabular}

The methodology utilised within this project was originally set out by Macgillvery (2009) who stated that a two-pronged approach was the most effective way to evaluate the value and effectiveness of learning support, taking into account both usage by students and their subsequent performance. As Learning Development support programmes are optional for students, measuring usage gives a measure of demand for the services and provides evidence that students and staff value the service (Macgillivray and Croft, 2011). By measuring student subsequent attainment, the research is measuring performance.

To understand the relationship of Learning Development tutorials with student attainment, three and a half years of campus taught undergraduate student profile and assessment data (excluding exams) was taken from the university records system (January 2014 to September 2017) and linked to a database of Learning Development tutorial information by student identification number. This meant 177,229 student assessments were included relating to 16,194 students. Examination assessments were excluded from the research, as, although Learning Development can help students with revision skills, they are not directly involved with the revision of topics examined. Campus-taught students include students attending campus and distance learning students who receive their teaching from staff based at the campus, for example, via Blackboard Collaborate.

The Learning Development appointment database collected information in relation to student ID, date of appointment and topic. Unfortunately, it did not collect information on the specific assessments that the student required support for. In order to be able to link appointments with assessments, student tutorials within 30 days prior to the assessment deadline were classified as using Learning Development to support that assessment. 1,501 (9.3 per cent) students had learning development tutorials within 30 days of an assessment deadline and this related to 3,682 assessments (2.1 per cent of assessments). This is problematic as some students work on assignments long before the 
30-day window or students may be assessed on more than one assignment within the 30 day time-frame. However, on average, full-time undergraduate students have 11.4 assessments within a university year so expanding this period further would have been problematic in determining which assignment was being supported. In addition, students with more than one assignment within the 30-day period could gain support for all of them. All tutorial appointment data back to 2008 was included in the research, as students in January 2014 could be second, third or fourth year students that may have had tutorials with Learning Development in previous years or on previous courses. For example, some nursing students undertake several stand-alone modules over many years.

Undergraduate tutorials were chosen for analysis in this research, as it was hypothesised that different groups of students and working practices would give differing results. Undergraduates were chosen as they formed most of the student body, and the one-toone support would target specific issues they had. This allowed the research to focus on understanding the impact of tutorials on undergraduate attainment and not to be influenced by different teaching approaches and groups with differing needs. Different support practices and student groups will be examined in future research.

Student assessment attainment was recorded in the database as grades. In order to examine the impact on attainment, these grades were converted to numerical values based on baseline value on the university undergraduate grading scales as seen in Table 2 (The University of Northampton, 2015). One sub-grade change equates to approximately 3 to 4 per cent. These numerical grades were then used to compare the assessment grades of students that had tutorials with Learning Development and those that did not. The research did not look at final degree grades, as some students were in their first or second years of study as well as the end of the study period.

\section{Table 2. Baseline percentage grade and letter grade for undergraduate degrees at the University of Northampton.}




\begin{tabular}{|c|c|}
\hline $\begin{array}{c}\text { Undergraduate } \\
\text { Numeric Grade }\end{array}$ & Letter Grade \\
\hline 90 & A + \\
\hline 78 & A \\
\hline 73 & A- \\
\hline 68 & B + \\
\hline 65 & B \\
\hline 61 & B- \\
\hline 58 & C \\
\hline 55 & C \\
\hline 51 & C- \\
\hline 48 & D+ \\
\hline 45 & D \\
\hline 41 & D- \\
\hline 38 & F+ \\
\hline 27 & F \\
\hline 13 & F- \\
\hline 4 & ZZ \\
\hline 3 & LG \\
\hline 2 & NG \\
\hline 1 & AG \\
\hline 0 & G \\
\hline & \\
\hline
\end{tabular}

The research examined the impact of tutorials on attainment by comparing students who had tutorials with those who did not. There are known difficulties in this approach to measuring the effectiveness of Learning Development support to students (Manalo et al., 2009; MacGillivray, 2009; Wilkins, 2015; Choudhary and Malthus, 2017). Firstly, students self-select to use the service, which may indicate a higher level of engagement with their studies. Secondly, tutorials are often running parallel to subject course teaching, making it difficult to understand the impact of additional support only. The research cannot assume causality between the attainment of students that do or do not attend tutorials with Learning Development. To assume causality there would need to be a comparison between a matched group of students that received tutorials and those that did not. In addition, students would have to attend tutorials rather than it being voluntary. This would raise ethical questions, as it would mean some students would not receive support when they might wish to. There are also likely to have been other confounding factors impacting student attainment other than just Learning Development tutorials. While this research cannot confirm that attending tutorials was the only reason for any increases in attainment, it is important that this was measured as it compares a population of students who use the service with those who do not, and looks for differences. 
To provide confidence in the findings, statistical inference testing was used. Chi-squared tests were conducted to examine if there was any relationship between the demographic profile of students and having Learning Development tutorials. When testing differences in attainment grades within demographic characteristics, such as faculty or ethnicity, analysis of variance (ANOVA) was used to determine whether there was a difference between groups of students.

\section{Results}

\section{Student profile}

Table 3 shows the student profiles of those who attended the university compared with those who attended at least one Learning Development tutorial within 30 days of an assessment deadline. The profile showed that a greater proportion of students attending tutorials were female, or from a black ethnic background or were mature students when compared to the rest of the university profile $(\chi 2(1, N=16192)=180.4, p<$ $0.01),(\chi 2(4, N=16192)=75.0, p<0.01)),(\chi 2(4, N=16192)=44.8, p<0.01)$. These results are similar to those found by Buchanan (2015).

Table 3. Student demographic profile of the university and for those attending Learning Development tutorials.

\begin{tabular}{|c|c|c|c|c|c|}
\hline \multirow{2}{*}{$\begin{array}{l}\text { Demographic } \\
\text { profile }\end{array}$} & \multirow[b]{2}{*}{ groups } & \multicolumn{2}{|c|}{$\begin{array}{l}\text { All University } \\
\text { students }\end{array}$} & \multicolumn{2}{|c|}{$\begin{array}{l}\text { Learning } \\
\text { Development tutorial } \\
\text { student profile }\end{array}$} \\
\hline & & Count & Percentage & Count & Percentage \\
\hline \multirow[t]{4}{*}{ Gender } & Female & 10452 & 64.54 & 1206 & 80.35 \\
\hline & Male & 5740 & 35.45 & 295 & 19.65 \\
\hline & Other & 2 & 0.01 & 0 & 0.00 \\
\hline & Total & 16194 & 100.0 & 1501 & 100.0 \\
\hline Ethnicity & White & 9174 & 56.65 & 708 & 47.17 \\
\hline
\end{tabular}




\begin{tabular}{|c|c|c|c|c|c|}
\hline & Mixed & 392 & 2.42 & 30 & 2.00 \\
\hline & Asian & 2417 & 14.93 & 256 & 17.06 \\
\hline & Black & 3187 & 19.68 & 400 & 26.65 \\
\hline & Other/Not & & & & \\
\hline & Known/refused & 1024 & 6.32 & 101 & 7.13 \\
\hline & Total & 16194 & 100.0 & 1501 & 100.0 \\
\hline Age at & 20 years or under & 8637 & 53.3 & 739 & 49.2 \\
\hline & 21-24 years & 3672 & 22.7 & 302 & 20.1 \\
\hline & $25-29$ years & 1214 & 7.5 & 128 & 8.5 \\
\hline & $30-39$ years & 1470 & 9.1 & 189 & 12.6 \\
\hline & 40 years and over & 1201 & 7.4 & 143 & 9.5 \\
\hline & Total & 16194 & 100.0 & 1501 & 100.0 \\
\hline Disability & No known disability & 14321 & 88.43 & 1260 & 83.94 \\
\hline & Disability & 1873 & 11.57 & 241 & 16.06 \\
\hline & Total & 16194 & 100.0 & 1501 & 100.0 \\
\hline
\end{tabular}

These results are partially explained by the students' faculty of study (Table 4). Students having tutorials with Learning Development were less likely to be from Arts, Science and Technology. This was the faculty with the greatest proportion of males (34 per cent of all males) and only 12 per cent of black ethnic students compared to 20 per cent across the university.

Table 4. Student faculties of study within the university and for those attending Learning Development tutorials.

\begin{tabular}{|l|l|l|l|}
\hline \multirow{2}{*}{ Faculty } & $\begin{array}{l}\text { All University } \\
\text { students }\end{array}$ & $\begin{array}{l}\text { Learning Development tutorial } \\
\text { student profile }\end{array}$ \\
\cline { 2 - 4 } & Count Percentage & & Count Percentage \\
\hline $\begin{array}{l}\text { Arts, Science and } \\
\text { Technology }\end{array}$ & $3582 \quad 22.12$ & & $152 \quad 10.13$
\end{tabular}




\begin{tabular}{|c|c|c|c|c|}
\hline Business and Law & 3417 & 21.10 & 320 & 21.32 \\
\hline Education and Humanities & 1756 & 10.84 & 254 & 16.92 \\
\hline Health and Society & 5692 & 35.15 & 562 & 37.44 \\
\hline Joint Honours & 1747 & 10.79 & 213 & 14.19 \\
\hline Total & 16194 & 100.00 & 1501 & 100.00 \\
\hline
\end{tabular}

Students with a disability were also more likely to attend tutorials with Learning Development (Table 3); 16 per cent attended Learning Development compared to 12 percent of all students across the university $(\chi 2(1, N=16332)=32.6, p<0.01)$. This was also found by Buchanan (2015). As part of their working practice they signposted students that need academic support to Learning Development. This finding provides evidence that Learning Development was reaching this group of students.

\section{Attainment results}

Table 5 shows student average attainment based on the number of tutorials attended by a student for an assignment. Both the mean and median average attainments are presented due to the skewness in the assessment grades. Twelve per cent of assessments were awarded a zero mark as they were either not handed in or not graded due to a lack of quality. Whilst being conscious of the skewness, given the large number of assessments, the mean value was used for the interpretation as it showed more detailed changes between the groups.

Table 5. Mean and median student grades by number of tutorials with Learning Development.

\begin{tabular}{|c|c|c|c|c|}
\hline \multirow{2}{*}{$\begin{array}{l}\text { Number of Learning Development } \\
\text { tutorials within } 30 \text { days of assessment } \\
\text { date }\end{array}$} & \multicolumn{4}{|l|}{ Grade } \\
\hline & Count & Mean & $\begin{array}{l}\text { Standard Error } \\
\text { of Mean }\end{array}$ & Median \\
\hline No tutorials & 173547 & 51.04 & .06 & 58.00 \\
\hline 1 & 2740 & 56.37 & .36 & 61.00 \\
\hline 2 & 647 & 57.93 & .68 & 61.00 \\
\hline 3 & 202 & 59.09 & 1.17 & 61.00 \\
\hline $4+$ & 93 & 55.15 & 1.82 & 58.00 \\
\hline
\end{tabular}


Across all undergraduate data, assessments with a Learning Development tutorial were on average just under 6 per cent higher (1-2 sub grades) than for those assessments without (No tutorial - $M=51.04$ per cent, one or more tutorials $-M=56.76$ per cent). Where students saw the team more than once within 30 days of their assessment deadline, their grades continued to increase by a further three per cent and peaked at three appointments.

Students seeing the team four or more times made improvement, but only one sub grade higher compared to no tutorials. Tables 6 and 7 show that these students were more likely to be studying within the faculties of Business and Law and Arts, Science and Technology, not studying joint honours $(\chi 2(4, \mathrm{~N}=3682)=21.0, \mathrm{p}<0.01)$ and from Asian or Black ethnic backgrounds $(\chi 2(4, N=3682)=17.4, p<0.01)$.

Table 6. Number of assessments based on faculty and number of tutorials.

\begin{tabular}{|c|c|c|c|c|}
\hline \multirow[b]{2}{*}{ Faculty } & & \multicolumn{2}{|c|}{ Number of tutorials } & \multirow[b]{2}{*}{ Total } \\
\hline & & $\begin{array}{l}1 \text { to } 3 \\
\text { tutorials }\end{array}$ & $\begin{array}{l}4 \text { or more } \\
\text { tutorials }\end{array}$ & \\
\hline $\begin{array}{l}\text { Arts, Science and } \\
\text { Technology }\end{array}$ & $\begin{array}{l}\text { Number of } \\
\text { assessments } \\
\% \text { within Number of } \\
\text { tutorials }\end{array}$ & $\begin{array}{l}382 \\
10.6 \%\end{array}$ & $\begin{array}{l}14 \\
15.1 \%\end{array}$ & $\begin{array}{l}396 \\
10.8 \%\end{array}$ \\
\hline Business and Law & $\begin{array}{l}\text { Number of } \\
\text { assessments } \\
\% \text { within Number of } \\
\text { tutorials }\end{array}$ & $\begin{array}{l}686 \\
19.1 \%\end{array}$ & $\begin{array}{l}31 \\
33.3 \%\end{array}$ & $\begin{array}{l}717 \\
19.5 \%\end{array}$ \\
\hline $\begin{array}{l}\text { Education and } \\
\text { Humanities }\end{array}$ & $\begin{array}{l}\text { Number of } \\
\text { assessments } \\
\% \text { within Number of } \\
\text { tutorials }\end{array}$ & $\begin{array}{l}704 \\
19.6 \%\end{array}$ & $\begin{array}{l}18 \\
19.4 \%\end{array}$ & $\begin{array}{l}722 \\
19.6 \%\end{array}$ \\
\hline Health and Society & $\begin{array}{l}\text { Number of } \\
\text { assessments } \\
\% \text { within Number of } \\
\text { tutorials }\end{array}$ & $\begin{array}{l}1188 \\
33.1 \%\end{array}$ & $\begin{array}{l}26 \\
28.0 \%\end{array}$ & $\begin{array}{l}1214 \\
33.0 \%\end{array}$ \\
\hline
\end{tabular}




\begin{tabular}{|l|l|l|l|l|}
\cline { 2 - 5 } & $\begin{array}{l}\text { Jumber of } \\
\text { assessments } \\
\text { \%on within Number of } \\
\text { tutorials }\end{array}$ & 629 & 4 & 633 \\
\hline Total & $\begin{array}{l}\text { Number of } \\
\text { assessments } \\
\text { \% within Number of } \\
\text { tutorials }\end{array}$ & 3589 & 93 & $17.2 \%$ \\
\hline
\end{tabular}


Table 7. Number of assessments based on ethnic background and number of tutorials.

\begin{tabular}{|c|c|c|c|c|}
\hline \multirow[b]{2}{*}{ Ethnicity } & & \multicolumn{2}{|c|}{ Number of tutorials } & \multirow[b]{2}{*}{ Total } \\
\hline & & $\begin{array}{l}1 \text { to } 3 \\
\text { tutorials }\end{array}$ & $\begin{array}{l}4 \text { or more } \\
\text { tutorials }\end{array}$ & \\
\hline Asian & $\begin{array}{l}\text { Number of } \\
\text { assessments } \\
\% \text { within Number of } \\
\text { tutorials }\end{array}$ & $\begin{array}{l}538 \\
15.0 \%\end{array}$ & $\begin{array}{l}22 \\
23.7 \%\end{array}$ & $\begin{array}{l}560 \\
15.2 \%\end{array}$ \\
\hline Black & $\begin{array}{l}\text { Number of } \\
\text { assessments } \\
\% \text { within Number of } \\
\text { tutorials }\end{array}$ & $\begin{array}{l}1056 \\
29.4 \%\end{array}$ & $\begin{array}{l}34 \\
36.6 \%\end{array}$ & $\begin{array}{l}1090 \\
29.6 \%\end{array}$ \\
\hline Mixed & $\begin{array}{l}\text { Number of } \\
\text { assessments } \\
\% \text { within Number of } \\
\text { tutorials }\end{array}$ & $\begin{array}{l}79 \\
2.2 \%\end{array}$ & $\begin{array}{l}2 \\
2.2 \%\end{array}$ & $\begin{array}{l}81 \\
2.2 \%\end{array}$ \\
\hline Unknown/refused/other & $\begin{array}{l}\text { Number of } \\
\text { assessments } \\
\% \text { within Number of } \\
\text { tutorials }\end{array}$ & $\begin{array}{l}251 \\
7.0 \%\end{array}$ & $\begin{array}{l}11 \\
11.8 \%\end{array}$ & $\begin{array}{l}262 \\
7.1 \%\end{array}$ \\
\hline White & $\begin{array}{l}\text { Number of } \\
\text { assessments } \\
\% \text { within Number of } \\
\text { tutorials }\end{array}$ & $\begin{array}{l}1665 \\
46.4 \%\end{array}$ & $\begin{array}{l}24 \\
25.8 \%\end{array}$ & $\begin{array}{l}1689 \\
45.9 \%\end{array}$ \\
\hline Total & $\begin{array}{l}\text { Number of } \\
\text { assessments } \\
\% \text { within Number of } \\
\text { tutorials }\end{array}$ & $\begin{array}{l}3589 \\
100.0 \%\end{array}$ & $\begin{array}{l}93 \\
100.0 \%\end{array}$ & $\begin{array}{l}3682 \\
100.0 \%\end{array}$ \\
\hline
\end{tabular}


Where students had seen Learning Development previously, their current assessment grade increased further (Table 8) - gaining just over two per cent extra compared to those seeing Learning Development for the first time and seven per cent (2 grades) compared to those assignments where the student was not supported by Learning Development.

Table 8: Number and average assessments grade based on Learning Development tutorials and whether the student had seen Learning Development previously.

\begin{tabular}{|l|l|l|l|l|l|}
\hline \multirow{2}{*}{$\begin{array}{l}\text { Number of Learning } \\
\text { Development tutorials } \\
\text { within 30 days of } \\
\text { assessment date }\end{array}$} & $\begin{array}{l}\text { Seen Learning } \\
\text { Development } \\
\text { No tutorial }\end{array}$ & $\begin{array}{l}\text { Greviously } \\
\text { Count }\end{array}$ & Mean & $\begin{array}{l}\text { Grade } \\
\text { Mean }\end{array}$ & Median \\
\cline { 2 - 7 } & No & 153422 & 50.60 & .06 & 58.00 \\
& Yes & 20125 & 54.35 & .15 & 58.00 \\
\cline { 2 - 7 } & No & 1911 & 55.65 & .43 & 58.00 \\
& Yes & 1771 & 57.96 & .42 & 61.00 \\
\hline
\end{tabular}

Table 9 shows the student demographic profile and differences in attainment for assessments with tutorial support compared to those without. Differences in student gender and whether they had a disability did not impact attainment (males, females, known disabled and not known disabled students had a mean increase of four to six per cent). 
Table 9. Mean and median assessment attainment based on demographics and whether the student had a tutorial with Learning Development.

\begin{tabular}{|c|c|c|c|c|c|c|c|c|c|c|c|}
\hline \multirow{3}{*}{\multicolumn{2}{|c|}{ Demographics }} & \multicolumn{8}{|c|}{ Tutorial with Learning Development within 30 days of assignment deadline } & \multirow{3}{*}{$\begin{array}{l}\text { Mean } \\
\text { Change }\end{array}$} & \multirow{3}{*}{$\begin{array}{l}\text { Median } \\
\text { Change }\end{array}$} \\
\hline & & \multicolumn{4}{|c|}{ No Tutorial } & \multicolumn{4}{|c|}{ Tutorial } & & \\
\hline & & Count & Mean & $\begin{array}{l}\text { Standard } \\
\text { Error of } \\
\text { Mean }\end{array}$ & Median & Count & Mean & $\begin{array}{l}\text { Standard } \\
\text { Error of } \\
\text { Mean }\end{array}$ & Median & & \\
\hline \multirow[t]{3}{*}{ Gender } & Female & 110007 & 52.44 & .07 & 58.00 & 2982 & 57.63 & .32 & 61.00 & 519 & 3 \\
\hline & Male & 63487 & 48.63 & .10 & 55.00 & 700 & 53.05 & .78 & 58.00 & 4.43 & 3 \\
\hline & Other & 53 & 25.36 & 3.93 & 0.00 & 0 & & & & & \\
\hline \multirow[t]{6}{*}{ Faculty } & $\begin{array}{l}\text { Arts, Science and } \\
\text { Technology }\end{array}$ & 46531 & 52.91 & .11 & 58.00 & 396 & 55.34 & .96 & 61.00 & 2.42 & 3 \\
\hline & Business and Law & 28446 & 50.19 & .15 & 58.00 & 717 & 60.91 & .65 & 65.00 & 10.73 & 7 \\
\hline & Education and & 26847 & 54.52 & .11 & 58.00 & 722 & 61.30 & .50 & 65.00 & 6.77 & \\
\hline & Humanities & & & & & & & & & & 7 \\
\hline & Health and Society & 50165 & 49.41 & .10 & 55.00 & 1214 & 53.93 & .56 & 58.00 & 4.52 & $?$ \\
\hline & Joint Honours & 21558 & 47.54 & .17 & 55.00 & 633 & 53.20 & .77 & 58.00 & 5.66 & 3 \\
\hline \multirow[t]{5}{*}{ Ethnicity } & Asian & 18983 & 51.48 & .16 & 58.00 & 560 & 56.93 & .75 & 61.00 & 5.45 & 3 \\
\hline & Black & 35586 & 40.89 & .13 & 48.00 & 1090 & 49.93 & .62 & 55.00 & 9.04 & 7 \\
\hline & Mixed & 4365 & 48.24 & .37 & 55.00 & 81 & 54.79 & 2.22 & 58.00 & 6.55 & 3 \\
\hline & White & 104205 & 54.68 & .07 & 61.00 & 1689 & 60.76 & .39 & 65.00 & 6.08 & 4 \\
\hline & Unknown/refused/other & 10408 & 49.58 & .23 & 55.00 & 262 & 59.67 & 1.02 & 61.00 & 10.10 & 6 \\
\hline \multirow[t]{2}{*}{ Disability } & & 22213 & 49.83 & .16 & 58.00 & 609 & 54.06 & .83 & 58.00 & 4.22 & 0 \\
\hline & No known disability & & 51.21 & .06 & 58.00 & 3073 & 57.30 & .32 & 61.00 & 6.09 & 3 \\
\hline \multirow{5}{*}{$\begin{array}{l}\text { Student's } \\
\text { age of } \\
\text { date of } \\
\text { enrolment } \\
\text { in } \\
\text { academic } \\
\text { year }\end{array}$} & 20 years or under & 96815 & 50.59 & 0.07 & 58.00 & 1443 & 56.76 & .48 & 61.00 & 6.16 & 3 \\
\hline & 21-24 years & 43104 & 51.13 & 0.11 & 58.00 & 1036 & 59.34 & .51 & 61.00 & 8.21 & 3 \\
\hline & $25-29$ years & 11469 & 52.45 & 0.22 & 58.00 & 306 & 54.74 & 1.22 & 61.00 & 2.29 & 3 \\
\hline & $30-39$ years & 12699 & 52.24 & 0.21 & 58.00 & 494 & 55.29 & .87 & 58.00 & 3.04 & 0 \\
\hline & 40 years and over & 9460 & 51.80 & 0.25 & 58.00 & 403 & 53.49 & .97 & 58.00 & 1.69 & 0 \\
\hline
\end{tabular}


Across all faculties, an increase in attainment was seen for those assessments where students sought support from Learning Development. Furthermore, there was a statistically significant difference across the faculties with having a Learning Development tutorial $(\mathrm{F}(4,208934)=11.958, \mathrm{p}<.001)$. The Faculties of Business and Law and Education and Humanities assessments saw the largest increase in attainment (mean increase 10.73 and 6.77 respectively). Arts, Science and Technology saw the least (mean increase 2.42). Interestingly, Arts, Science and Technology students were less likely to have tutorials with Learning Development compared to other faculties and it is these students who gained less from tutorials. This could potentially be explained in part by the programmes of study, as Learning Development tutorials would not assist creative work or scientific experiments.

Students from a black ethnic background had a greater increase in attainment from tutorials with Learning Development compared to other ethnic backgrounds (mean increase 9.04 per cent, median increase 8 per cent $)(F(4,208934)=5.352, p<.001)$. However, they also had on average lower attainment (mean grade 41.5 per cent for black students; other ethnic backgrounds' mean grades between 48.4 and 51.6 per cent). Given this, the greater increase in part could potentially be due to their attainment level and potential for improvement.

Students' age had an impact on attainment improvement $(\mathrm{F}(4,208934)=13.374, \mathrm{p}<$ .001). Students aged 25 and below at enrolment onto their academic programme saw an average increase in attainment of between 6 and 8 per cent. However, students aged 25 and above saw only 1.6 to 3 per cent increase. Further research showed that the mature students who gained less from Learning Development tutorials had no specific demographic profile in terms of faculty, programme studied, ethnicity or mode of study.

\section{Discussion}

The purpose of this research was to understand whether Learning Development tutorials have an impact on student attainment. The findings showed that student assignments improved by one to two sub grades (six per cent) where students had tutorial support. This 
finding is consistent with research by Manalo et al. (2009), MacGillivray (2009) and Choudhary and Malthus (2017) who also found a positive impact on attainment from tutorials. The results from previous research were already encouraging but the results from this study give further confidence that tutorials impact student attainment, due to the large population size.

A continued tutorial relationship with Learning Development increased attainment in two ways. Firstly, attainment increased further where students had two or three tutorials for the same assignment (seven to eight per cent increase). The results showed that attainment peaked at three tutorials, with students having more tutorials still gaining in terms of attainment when compared to those with no tutorials but at a lower level. One possible explanation could be that students seeking support from Learning Development more than three times lack independence in applying tutorial knowledge rather than gaining new learning from additional tutorials. Secondly, a continual relationship between students and Learning Development tutorials where students seek support for more than one assignment increased student results a further two per cent. Having a tutorial with Learning Development impacted future assignment results even when there was no specific further support for these assignments, suggesting that skills learnt have been utilised in future assignments. This is in line with research showing the impact of academic advising on student success (Bourne, 2006; Young-Jones et al., 2013). Young-Jones et al. found that the continued relationship with the academic advisor (students meeting at least once per semester) impacted student success when compared to those meeting less frequently. Bourne's (2006) report for the National Audit Office also supports this by recommending the improved support of academic tutoring systems to improve student chances of success and improve retention.

The Learning Development team at the University of Northampton is seen as modelling exemplary practice that is valued by students (QAA, 2009). However, there has been limited published research into the impact on attainment. These findings are significant as they show the importance of Learning Development tutorials and the impact they can have on student grades. The question needs to be asked why more students do not use tutorials. This could be simply that the impact of tutorials until now has been unknown and therefore marketing activity could increase student numbers. It may be that students who see Learning Development have different study support needs than those who do not. 
Student engagement is likely to play a role, since students who seek help from Learning Development have already begun the engagement process. Winograd and Rust (2014) analysed the reasons why students did not seek academic support when it was needed. They found that students who felt less comfortable in the university environment were less likely to seek support, as it created feelings of inadequacy and inferiority; that self-stigma was a significant contributor in not seeking help as students felt that professors and other students would look down on them due to their poor performance; and that males rather than females associated academic help-seeking with inferiority and inadequacy. The paper also found positive contributors to students seeking academic support included awareness of academic support and students' greater sense of belonging within campus. Additional marketing of Learning Development services may therefore help students seek the support they need.

The first part of the research showed the demographic profile of students of the university and those attending Learning Development tutorials: students attending tutorials were more likely to be female, from a black ethnic background, have a disability and be studying with the Faculty of Health and Society compared to the university student profile. The majority of these finding were in line with Buchanan's (2015) research, which showed that female, BME and disabled students were more likely to use the service at her university. As seen previously, Winograd and Rust (2014) suggested that females rather than males may attend tutorials, as they were less likely to see seeking academic support as a sign of inferiority and inadequacy. This research goes further in breaking down the ethnic background of student and shows that it is black students rather than those from a minority ethnic or Asian background that are more likely to use Learning Development tutorials. However, the link between ethnicity and faculty of study shows that ethnicity may not be the reason for students attending tutorials, as the faculty using Learning Development the most for tutorials was Health and Society, which had a higher proportion of black students, and the faculty that used the Learning Development the least was the faculty of Arts, Science and Technology which also had the lowest number of black students. Further research is required to understand the drivers. The finding that students with a disability are more likely to use the service is not a surprising result as other student support teams from within the university signpost Learning Development to provide academic support when needed. This finding was also reflected by Buchanan (2015) who saw $23 \%$ of 
students with a learning disability compared to $16 \%$ of the university population in the academic year 2013/14.

A surprise finding from the research was that mature students gained less from tutorials than younger students did. Multiple studies have shown that mature students gain similar levels of attainment to younger students ( Richardson, 1995; Richardson and Woodley, 2003; Crosling et al., 2009). Therefore, further research will be required to understand the characteristics of mature students that attend tutorials and why they gain less from the support.

One of the limitations of this study is that of causality. While there are differences in attainment for students who have tutorials with Learning Development, we cannot say that is it the tutorials that caused this. It is possible that students who have tutorials with Learning Development are of a higher attainment level before seeing the team or the fact that they have chosen to seek support means that they are already engaged in the learning process. This issue has been addressed in similar research looking at the impact of tutorials ( MacGillivray, 2009; Manalo et al., 2009) who concluded that these were limitations of the research but examining the patterns from the research would provide conclusions into the impact of tutorials. Potential further research could explore a longitudinal view of student attainment results, by looking at individual student attainment prior to seeing Learning Development and comparing them with after. However, this also has problems as individual assessments vary, and the level of assessment increases in difficulty as students progress.

In addition, a limitation of the study is that it only compares students who attend tutorials with those that do not. It does not account for whether the student had support from Learning Development at drop-ins or workshops or other influencing factors such as embedded faculty support, the difficulty of different assessments, level of study or student ability.

\section{Conclusion}


Understanding the impact of Learning Development tutorials is important to students, the university, the Learning Development team and Learning Development as a community of practice. The impact on students is not just student attainment, but also how it improves their confidence and engagement in their studies. The goal for students is to get a university degree that they can be proud of. This research showed that students who have Learning Development tutorials have higher attainment than those who do not. Learning Development teams are a finite resource and cannot advise all students within the university. However, with such an impact on student grades, the team needs to look at how they can improve student attainment further in the areas where less impact has been found - especially mature students and those from Arts, Science and Technology - and support more students where there are gaps in use of the service.

\section{References}

Blair, T. (1999) British Political Speech. Speech Archive. Available at:

http://www.britishpoliticalspeech.org/speech-archive.htm?speech=205 (Accessed: 6 June 2019).

Bourne, J. (2006) Report by the controller and Editor General. HC 616 Staying the course: The retention of students in higher education. Available at: https://www.nao.org.uk/wp-content/uploads/2007/07/0607616.pdf (Accessed: 15 May 2018).

Buchanan, A. (2015) 'Identifying users of learning development to inform future practice', Journal of Learning Development in Higher Education, (9), pp. 1-16.

Choudhary, R. and Malthus, C. (2017) 'The impact of targeted mathematics/numeracy tutorials on maths anxiety, numeracy and basic drug calculation exam marks', Journal of Academic Language and Learning, 11(1). 
Crosling, G., Heagney, M. and Thomas, L. (2009) 'Improving Student Retention in Higher Education: Improving teaching and learning'. Australian Universities Review, 51(2), pp. 9-18.

Hilsdon, J. (2011) 'What is learning development?', in Hartley, P., Keenan, C. and Sinfield, S. and Verity, M. (eds.) Learning Development in Higher Education. Basingstoke: Palgrave Macmillan, pp. 13-27.

MacGillivray, H. (2009) 'Learning support and students studying mathematics and statistics', International Journal of Mathematical Education in Science and Technology, 40(4), pp. 455-472. doi: 10.1080/00207390802632980.

Macgillivray, H. and Croft, T. (2011) 'Understanding evaluation of learning support in mathematics and statistics', International Journal of Mathematical Education in Science and Technology, 42(2), pp. 189-212. doi:

10.1080/0020739X.2010.519801.

Manalo, E., Marshall, J. and Fraser, C. (2009) Student Learning Support Programmes that demonstrate tangible impact on student retention, pass rates, and/or completion. Available at: https://akoaotearoa.ac.nz/download/ng/file/group-5/student-learningsupport-programmes-that-demonstrate-tangible-impact-on-retention-pass-rates-completion.pdf (Accessed: 8 June 2018).

Murphy, T. E., Gaughan, M., Hume, R. and Moore, S. G. (2010) 'College Graduation Rates for Minority Students in a Selective Technical University: Will Participation in a Summer Bridge Program Contribute to Success?', Educational evaluation and policy analysis. NIH Public Access, 32(1), pp. 70-83. doi: 10.3102/0162373709360064.

Perkin, G., Lawson, D. and Croft, T. (2012) Mathematics learning support in UK higher education the extent of provision in 2012 b. Available at: http://www.mathcentre.ac.uk/ (Accessed: 21 February 2019).

QAA (2009) University of Northampton - Institutional audit. Available at: 
http://www.qaa.ac.uk/en/ReviewsAndReports/Documents/The University of Northampton/University-Of-Northampton-IA-09.pdf.

Richardson, J. T. E. (1995) 'Mature students in higher education: II. An investigation of approaches to studying and academic performance', Studies in Higher Education. Taylor and Francis Group , 20(1), pp. 5-17. doi: 10.1080/03075079512331381760.

Richardson, J. T. E. and Woodley, A. (2003) 'Studies in Higher Education Another Look at the Role of Age, Gender and Subject as Predictors of Academic Attainment in Higher Education', Studies in Higher Education, 28(4), pp. 475-493. doi: 10.1080/0307507032000122305.

Strayhorn, T. L. (2011) 'Bridging the Pipeline: Increasing Underrepresented Students' Preparation for College Through a Summer Bridge Program', American Behavioral Scientist, 55(2), pp. 142-159. doi: 10.1177/0002764210381871.

The University of Northampton (2015) What are the undergraduate and post-graduate grading scales? NILE FAQs. Available at: https://mypad.northampton.ac.uk/nilefaq/2015/07/28/what-are-the-undergraduateand-post-graduate-grading-scales/ (Accessed: 9 May 2018).

Universities UK (2017) Patterns and Trends in UK Higher Education 2017. London. Available at: https://www.universitiesuk.ac.uk/facts-and-stats/data-andanalysis/Documents/patterns-and-trends-2017.pdf (Accessed: 24 May 2018).

Wibrowski, C. R., Matthews, W. K. and Kitsantas, A. (2017) 'The Role of a Skills Learning Support Program on First-Generation College Students' Self-Regulation, Motivation, and Academic Achievement: A Longitudinal Study', Journal of College Student Retention: Research, Theory and Practice, 19(3), pp. 317-332. doi: $10.1177 / 1521025116629152$.

Wilkins, L. (2015) 'Maybe we could just count the boxes of chocolates? Measuring the impact of Learning Development mathematics support for undergraduate students', Journal of Academic Language and Learning Journal of Academic Language and 
Learning, 9(2), pp. A91-115. Available at: http://ro.uow.edu.au/asdpapers/514 (Accessed: 8 June 2018).

Winograd, G. winograg@newpaltz. ed. and Rust, J. P. (2014) ‘Stigma, Awareness of Support Services, and Academic Help-Seeking Among Historically Underrepresented First-Year College Students', Learning Assistance Review (TLAR), 19(2), pp. 17-41. Available at:

https://nclca.wildapricot.org/resources/Documents/Publications/TLAR/Issues/19 2.p df (Accessed: 5 May 2020)

Young-Jones, A. D. , Burt, T. D., Dixon, S. and Hawthorne, M. J. (2013) 'Academic advising: does it really impact student success?', Quality Assurance in Education. Emerald Group Publishing Limited, 21(1), pp. 7-19. doi: $10.1108 / 09684881311293034$.

\section{Author details}

Alison Loddick is a Chartered Statistician and a Learning Development Tutor in Mathematics and Statistics at the University of Northampton supporting students in their academic studies through workshops and 1-1 tutorials. Her academic research is focussed on the evaluation of the Learning Development service on students in terms of attainment, retention, engagement, confidence and satisfaction; and whether different groups of students benefit from the service.

Kate Coulson is a qualified librarian, teacher and Senior Fellow of the HEA. She is Head of Learning Development at the University of Northampton where she leads a team of academic tutors who support and advise all students with their academic and study skills. Previously her academic research concentrated on the self-reported confidence of students' academic skills but more recently she has focussed on the engagement, attainment and progression of students utilising her team. 